\title{
Działalność Leona Cyfrowicza (1844-1904) na rzecz sierot w Krakowskim Towarzystwie Dobroczynności
}

\section{The Work of Leon Cyfrowicz (1844-1904) for Orphans in the Krakow Charitable Society}

\begin{abstract}
ABSTRAKT
Celem artykułu jest ukazanie aktywności Leona Cyfrowicza, studenta i wykładowcy Uniwersytetu Jagiellońskiego, ukierunkowanej na pomoc ubogim dzieciom i sierotom pozostajqcym pod opiekq Krakowskiego Towarzystwa Dobroczynności. Pomoc ta miała na celu umożliwienie im zdobycia elementarnego wykształcenia oraz przygotowania do pracy zawodowej.

Artykuł został przygotowany na podstawie materiałów źródłowych zgromadzonych w Archiwum Narodowym w Krakowie oraz Bibliotece Jagiellońskiej. Analizowano rękopisy protokołów posiedzeń Rady Ogólnej Krakowskiego Towarzystwa Dobroczynności, korzystano również z wydawanych drukiem „Roczników Krakowskiego Towarzystwa Dobroczynności". Analizie poddano również publikacje Cyfrowicza. Zastosowano jakościowq analizę materiału źródłowego.
\end{abstract}

SLOWA KLUCZOWE Cyfrowicz Leon, opieka, sierota, Krakowskie Towarzystwo Dobroczynności, dobroczynność

\section{KEYWORDS}

Cyfrowicz Leon, care, orphan, Krakow Charity Society, charity

SPI Vol. 23, 2020/2

ISSN 2450-5358

e-ISSN 2450-5366

DOI: 10.12775/SPI.2020.2.002

Nadesłano: 1.04.2020

Zaakceptowano: 19.05.2020

Artykuły i rozprawy 
Ustalono, że Cyfrowicz zaangażowany był w działalność tzw. wydziałów Krakowskiego Towarzystwa Dobroczynności, brał czynny udział w posiedzeniach zarzadu Towarzystwa, był członkiem Komisji Szkolnej odpowiedzialnej za opiekę, wychowanie i kształcenie dzieci. Z jego inicjatywy utworzono tzw. salę rzemiosł, przemianowanq na szkołę rzemiosł.

kqczenie pracy naukowej i zawodowej z działalnościq dobroczynna nadal stanowi pożqdanq formę aktywności człowieka. Podjęta przez Cyfrowicza działalność dobroczynna jest przykładem zaangażowania w pomoc ludziom ubogim, zwłaszcza dzieciom, czynnego włączenia się w prace Krakowskiego Towarzystwa Dobroczynności.

\section{ABSTRACT}

The aim of the article is to present the work of Leon Cyfrowicz, a student and lecturer at the Jagiellonian University, aimed at helping poor children and orphans under the care of the Krakow Charitable Society. His aim was to enable them to gain an elementary-school education and to prepare them for professional work.

The article was based on source materials collected from the National Archive in Krakow and the Jagiellonian Library. Manuscripts of the minutes of meetings of the General Council of the Krakow Charitable Society were analyzed, as were the "Yearbooks of the Krakow Charitable Society." Cyfrowicz's publications were also used. A qualitative analysis of the source material was done.

It was established that Cyfrowicz was involved in the activities of the "Departments of the Krakow Charitable Society"; he took an active part in the Society's board meetings, was a member of the School Committee, and was responsible for the care, upbringing, and education of the children. On his initiative, the "Crafts Room" was established, renamed the School of Crafts.

Combining scientific, professional, and charitable work is still a desirable form of human activity. The charitable work done by Cyfrowicz is an example of being involved in helping poor people, especially children, actively participating in the work of the Krakow Charitable Society. 


\section{Wstęp}

Tradycje dobroczynne miały w Krakowie swoją długą historię, wiele znakomitych postaci podejmowało trud wspomagania ubogich dorosłych oraz dzieci. Znaczacy udział $w$ tych działaniach mieli również wykładowcy Uniwersytetu Jagiellońskiego, określani mianem „prawdziwej elity wśród inteligencji krakowskiej” (Karolczak 1995: 215). Ich biografie, jak zaznaczył Julian Dybiec, ukazują przede wszystkim ich wkład w rozwój nauki i jej upowszechnianie (Dybiec 2011: 280-282). Dodać należy, że rektorzy oraz nauczyciele uniwersytetu łączyli działalność naukową i dydaktyczną z zaangażowaniem w prace stowarzyszeń niosących pomoc mieszkańcom miasta, wspierali również swoim autorytetem akcje dobroczynne. W tradycję uniwersytecką wpisała się pomoc ubogim dzieciom, uczniom krakowskich szkól, zubożałym studentom. Nazwiska przedstawicieli UJ znajdujemy w wykazach członków najstarszego, świeckiego stowarzyszenia w Krakowie, podejmującego opiekę nad ubogimi i chorymi starszymi ludźmi oraz sierotami, tj. Krakowskiego Towarzystwa Dobroczynności (Pamiętnik Towarzystwa Dobroczynności... 1968: 241-245). Wielu profesorów oraz doktorów czynnie włączało się w działalność Towarzystwa, od jego utworzenia w 1816 roku, aż do rozwiązania go przez władze komunistyczne w roku 1951. Zapraszani byli do pełnienia funkcji protektorów, prezesów, zasiadali w Radzie Ogólnej kierującej Towarzystwem, angażowali się w prace poszczególnych wydziałów, służyli pomocą prawniczą, medyczną, podejmowali wysiłki nad doskonaleniem form opieki, a także wychowania i kształcenia podopiecznych. Aktywność ta stanowiła ich wkład w rozwój systemu oświaty, który tworzą „placówki szkolne, pozaszkolne instytucje edukacji permanentnej i równoległej, a także instytucje opieki nad dzieckiem" (Meissner 2011: 9).

Celem podjętych badań było ustalenie, jakie działania podejmował Leon Cyfrowicz, aby wspomóc ubogie dzieci pozostające pod opieką Krakowskiego Towarzystwa Dobroczynności (dalej w skrócie: KTD) w prowadzonym przez to Towarzystwo zakładzie. Cyfrowicz był docentem nauki administracji i austriackiego ustawodawstwa, od 1886 roku profesorem Uniwersytetu Jagiellońskiego. Przedmiotem zainteresowania były działania Cyfrowicza, które miały wspomóc dzieci pozostające pod opieką KTD w zdobyciu elementarnego 
wykształcenia, jak również umiejętności praktycznych. Uwagą objęto również dorobek piśmienniczy Cyfrowicza poświęcony kwestiom ubóstwa, upowszechniania form pomocy dobroczynnej, jak również działalności KTD. Kwestie te dopełniają obraz aktywności naukowej i dydaktycznej Cyforwicza, wykładowcy na UJ, a także opiekuna sierot w Krakowskim Towarzystwie Dobroczynności. Wymieniony obszar jego pracy dobroczynnej nie był szerzej podejmowany w dotychczasowych badaniach. Jego działalność w tym zakresie przyczyniła się do zmian, jakie zostały podjęte przez KTD w kwestii nauczania i wychowania dzieci w zakładzie Towarzystwa w drugiej połowie XIX wieku.

Podstawowym materiałem źródłowym były akta KTD, znajdujące się w Archiwum Narodowym w Krakowie, w zespole 547. Przeanalizowano również materiały zgromadzone w Archiwum Uniwersytetu Jagiellońskiego, jednakże nie poczyniono w oparciu o nie nowych ustaleń. Istotnych informacji dostarczyły również materiały źródłowe drukowane, znajdujące się w zbiorach wymienionego Archiwum oraz Biblioteki Jagiellońskiej, zwłaszcza „Roczniki Krakowskiego Towarzystwa Dobroczynności” oraz publikacje autorstwa Cyfrowicza. Pod uwagę wzięto materiały poświęcone jego osobie i działalności zamieszczane w „Czasie”, „Nowej Reformie” oraz w „Gazecie Krakowskiej”. Analizowano okres od lat 70. XIX wieku do początku XX wieku, obejmujący lata współpracy Cyfowicza z KTD.

Dotychczas postaci Cyfrowicza poświęcono uwagę w krótkim biogramie, który zamieszczony został w Encyklopedii Krakowa (Cyfrowicz Leon... 2000: 132). Jego udział w powstaniu styczniowym 1863 roku odnotowała Janina Bienarzówna, pisząc o dziejach Krakowa w drugiej połowie XIX wieku. Na temat działalności $\mathrm{Cy}$ frowicza na Uniwersytecie Jagiellońskim wspominała Maria Stinia, ukazując dzieje tej uczelni w latach 1871-1914; wątek pełnionej przez niego roli sekretarza kancelarii UJ podjął Przemysław Żukowski (Bieniarzówna 1965: 222; Stinia 2014: 69, 177, 187; Żukowski 2016: 349-363). W wymienionych materiałach analizowano przede wszystkim działalność Cyfrowicza jako człowieka nauki, pracownika uniwersytetu: nauczyciela, sekretarza kancelarii UJ. W prezentowanym artykule zwrócono uwagę na jego współpracę z KTD, która przyczyniła się do doskonalenia form opieki nad najmłodszymi podopiecznymi Towarzystwa. 


\section{Działalność zawodowa, polityczna i społeczna Leona Cyfrowicza}

Leon Cyfrowicz urodził się w Krakowie 1 IV 1844 roku, ukończył tam gimnazjum św. Anny, po czym studiował na UJ na Wydziale Prawa („Nowa Reforma” 1904: 3; Cyfrowicz Leon... 2000: 132; Stinia 2014: 69; Żukowski 2016: 355). Włączył się w ruch niepodległościowy powstania styczniowego 1863 roku, pomimo restrykcji grożących studentom i zakazów ze strony władz uczelni (Grodziski 1995: 211; W trzydziesta rocznice... 1893: 4). Po aresztowaniu 1 III 1864 roku Adolfa Aleksandrowicza, powstańczego naczelnika Krakowa, na jego miejsce wybrany został ksiądz Adam Słotwiński, na zastępcę zaś powołano Cyfrowicza (Zgórniak 1964: 160; Bieniarzówna 1965: 222). W opinii Mariana Zgórniaka, piszącego o zaangażowaniu studentów w działania niepodległościowe w Krakowie w latach 1846-1864, Cyfrowicz może być zaliczony do grupy określanej lewicą czerwonych. Wziął on także udział w podjętej przez studentów UJ próbie zalegalizowania działalności Czytelni Akademickiej (Zgórniak 1964: 162, 165). Wszedł w skład komisji, razem z Gustawem Romerem oraz Władysławem Skrzydylko, przygotowującej statut, który został zaakceptowany przez Namiestnictwo w 1867 roku (Miśko 1891: 29). Po ukończeniu studiów nadal pozostał związany z uniwersytetem. W 1869 roku uzyskał stopień doktora praw. W roku 1879 został docentem prywatnym UJ w zakresie nauki administracji i austriackiego ustawodawstwa administracyjnego, od 1882 roku sekretarzem kancelarii UJ i - jak odnotowano w „Nowej Reformie” - był wówczas „prawą ręką każdoczesnego rektora”(„Nowa Reforma” 1904: 3). W 1886 roku został mianowany na profesora tytularnego $\mathrm{z}$ tytułem i charakterem profesora nadzwyczajnego nauki administracji i austriackiego prawa administracyjnego (Żukowski 2016: 356). Kształcił studentów jako wykładowca rachunkowości państwowej. W latach 1869-1881 (1869-1884 - według Stinia 2014: 69) pracował w redakcji dziennika krakowskiego „Czas” razem z Ludwikiem Dębickim i Józefem Kleczyńskim (Ksiegra pamiq̨tkowa na dzierwięćdziesiolecie dziennika „Czas” 1938: 60). Zaangażowany był również w przygotowania 500-lecia istnienia UJ w 1900 roku, znaczącej uroczystości dla miasta i Polaków, która ściągnęła do Krakowa przedstawicieli nie tylko wszystkich ziem polskich, uczelni, ale i wielu znakomitych uniwersytetów europejskich (Flach 1917: 73). Od 1876 roku był członkiem, jak 
również radcą Arcybractwa Miłosierdzia i Banku Pobożnego w Krakowie, przez 20 lat pełnił funkcję członka Rady Miasta Krakowa, był prezydentem krakowskiej filii austriackiego Towarzystwa Czerwonego Krzyża (Książka pamiatkowa... 1884: 313; Wybory 1881: 1). W 1888 roku odznaczony został Krzyżem Orderu Franciszka Józefa. W dniu 23 V 1904 roku zmarł w Krakowie po kilkudniowej chorobie i przebytym ataku apoplektycznym, pochowany został na Cmentarzu Rakowickim („Nowa Reforma” 1904: 3). Jak podkreślono we wspomnieniu pośmiertnym, zamieszczonym w „Nowej Reformie", Cyfrowicz działał nie tylko na polu zawodowym, politycznym, ale i społecznym. Współpracował przez 30 lat z Krakowskim Towarzystwem Dobroczynności. Pełnił w nim istotną dla organizacji opieki nad dziećmi funkcję przewodniczącego wewnętrznego organu Towarzystwa, jakim była Komisja Szkolna.

\section{Publikacje Leona Cyfrowicza}

Dorobek piśmienniczy Cyfrowicza można podzielić na trzy obszary. Pierwsza grupa publikacji dotyczyła kwestii prawnych i administracyjnych. Drugim istotnym obszarem były materiały przygotowywane dla nauczycieli ówczesnych szkół. Wykorzystywał w nich swoją wiedzę z zakresu prawa oraz wyjaśniał przepisy i wytyczne szkolne, podawał zasady odbywania egzaminów. Trzecia część publikacji związana była z jego działalnością dobroczynną i służyła upowszechnianiu tej formy pomocy dzieciom i dorosłym, a także prezentacji informacji biograficznych o postaciach, które angażowały się w dobroczynność.

Już w 1869 roku wydał w Krakowie Zdania z różnych gatęzi prawa i umiejętności politycznych, których po odbyciu egzaminów ścistych w celu uzyskania godności doktora obojga praw na c.k. Uniwersytecie Jagiellonskim w Krakowie Leon Cyfrowicz Krakowianin we srodę 10 Marca 1869 o godz. 12 w potudnie w Kolegium Prawniczem publicznie bronić sie podejmuje (Cyfrowicz 1869). Na łamach tej siedmiostronicowej broszury poddawał dyskusji kwestie, które dotyczyły prawa rzymskiego, kanonicznego, polskiego, filozofii prawa i prawa narodów, prawa i postępowania cywilnego austriackiego, prawa wekslowego i handlowego, prawa i postępowania karnego austriackiego, umiejętności politycznych i statystyki. Pogłębił tematykę z zakresu prawa 
w wydanej w 1889 roku publikacji pt. Wyktad austriackiego prawa administracyjnego (Cyfrowicz 1889).

Pomocne dla nauczycieli w przygotowaniu się do egzaminów były wydane w 1884 roku przepisy oraz objaśnienia w języku polskim dla kandydatów na nauczycieli mających podjąć pracę w gimnazjach i szkołach realnych (Cyfrowicz 1884a). Jak sam zaznaczył w słowie wstępnym, publikacja służyć miała zarówno komisjom, jak i osobom zdającym egzaminy. W związku z tym, że wydane 7 II 1884 roku przepisy stanowiły „zasadniczy przełom w systemie egzaminowania” oraz wprowadzały - zamiast dotychczas obowiązującego podziału na nauczycieli klas - ujednoliconą kategorię nauczycieli i przedmiotów, tym istotniejsze było ich zrozumienie (Chodakowska 1990: 158). Cyfrowicz wyjaśniając przepisy poruszał również kwestie dotyczące metodyki geografii i historii. Jak potrzebne były takie opracowania, świadczy wypowiedź Stefanii Sempołowskiej, która zaznaczyła w 1905 roku, że wszystkie plany i urzędowe instrukcje wydawane były w języku niemieckim, co znacznie utrudniało ich odbiór i zrozumienie (Sempołowska 1906: 4,7).

Dążąc do zwiększenia zainteresowania mieszkańców Krakowa dobroczynnością oraz przekonania ich do czynnego udziału we wspieraniu istniejących towarzystw, przygotował publikację prezentującą zarys działalności organizacji dobroczynnych w Krakowie. Przedstawiał w niej podejmowane w Krakowie działania dobroczynne, osoby zaangażowane w pomoc, a także potrzeby, jakie miały towarzystwa i zakłady. Opublikował ją pod koniec lat 70. XIX wieku, zwracając uwagę na konieczność czerpania wzorów z miast europejskich w zakresie organizacji dobroczynności publicznej. Wskazywał, że ludzie potrzebujący w Krakowie przez wiele lat byli wspierani przez dobroczynność prywatną, inspirowaną i realizowaną przez duchowieństwo, jak i osoby świeckie. W jego opinii dobroczyńcy mieli ogromne zasługi w organizowaniu pomocy ludziom ubogim, ale bardziej korzystne byłoby połączenie wysiłków pojedynczych osób i stowarzyszeń. Pozwoliłoby to na uniknięcie sytuacji, kiedy ten sam ubogi korzystał ze wsparcia różnych towarzystw i osób, zawężając w ten sposób możliwość pomocy innym (Cyfrowicz 1878: 9). W kolejnej publikacji wydanej w połowie lat 80. XIX wieku analizowal pod kątem prawnym zagadnienia zubożenia, biedy oraz ich konsekwencje (Cyfrowicz 1885). 
Wspomagając KTD w pozyskiwaniu funduszy na realizację zadania opieki nad ołtarzem i obrazem Matki Boskiej w Bramie Floriańskiej wydał w 1884 roku opracowanie pt. Obraz Matki Boskiej i skarbonka ubogich w Bramie Floriańskiej w Krakowie (Cyfrowicz 1884b). Zaznaczył w nim, jak ważne było to miejsce dla krakowian i odwiedzających miasto gości. We wstępnych rozważaniach przedstawił dotychczasowe ustalenia historyków na temat dziejów Bramy Floriańskiej, obrazu tam umieszczonego, a także wierzeń z nim związanych (Cyfrowicz 1884b: 1-8). Czytelnik mógł się również dowiedzieć, że przy obrazie Matki Boskiej odbywały się nabożeństwa, w których uczestniczyła zawsze duża liczba wiernych. Miały one nie tylko wymiar religijny, ale również patriotyczny. Zaznaczył, że przy ołtarzu umieszczona była skarbonka, do której mieszkańcy Krakowa i okolic wrzucali pieniądze przeznaczane na rzecz ubogich podopiecznych KTD (Cyfrowicz 1884b: 22, 25-26, 42-43).

Cyfrowicz poświęcił również uwagę osobom, które wspierały działalność KTD. In memoriam powstała broszura poświęcona Ludwikowi Georgenowi, radcy KTD oraz członkowi Komisji Szkolnej. Podkreślając cechy jego charakteru, za szczególnie cenne uznał wytrwałość, którą zdobył pracując jako guwerner, a także chęć służenia dzieciom i młodzieży. Przypomniał, że założył on w Krakowie w 1869 roku pensjonat, a jego praca uzyskała pozytywną ocenę i przyniosła mu opinię dobrego i zdolnego pedagoga. Zaznaczył, że jako członek KTD, pracując w Komisji Szkolnej, Georgen: „Z zamiłowaniem odbywał inspekcje szkolne, gdy kolej na niego przyszła”. Podsumowując wypowiedź na temat działalności Georgena, wyraził przekonanie, że człowiek, który jest dobrym obywatelem, nauczycielem, uczciwie pracuje i wychowuje młode pokolenie, jest również dobrym członkiem rodziny (Cyfrowicz 1879: 7).

\section{Zaangażowanie w działalność Krakowskiego Towarzystwa Dobroczynności}

W dniu 16 VI 1872 roku, podczas zebrania Rady Ogólnej, ówczesny prezes KTD hrabia Konstanty Hoszowski (1805-1884) poprosił Cyfrowicza o zamieszczanie w „Czasie” informacji z posiedzeń Rady (Protokół z posiedzenia zwyczajnego Rady Ogólnej w dniu 
16 czerwca 1872: 218). Można przyjąć, że wywiązał się ze zleconego mu zadania, ponieważ na łamach dziennika można znaleźć wymienione informacje. Realizował również czynności wynikające ze statutowych zadań organów KTD, zwanych Wydziałami, w skład których wchodził jako radca. Pod koniec lat 70.XIX wieku, kontynuując prace poprzednich sekretarzy Józefa Więckowskiego oraz Józefa Głębockiego, uporządkował księgi funduszowe KTD. Pracę tę prezes Hoszowski ocenił jako wykonaną „wzorowo, z poświęceniem”, podkreślając zarazem, że Cyfrowicz „całość najdokładniej uporządkował i do końca bez żadnego osobnego wynagrodzenia doprowadził" (Hoszowski 1882: 14). Jako radca zobowiązany był brać udział w zebraniach Rady Ogólnej i realizować zadania Wydziału Gospodarczego, a także Wydziału Spisu, które kolejno reprezentował i przewodniczył temu ostatniemu (Rocznik LXVII Krakowskiego... 1886: 13; Rocznik LXXI Krakowskiego... 1890: 9).W 1875 roku wybrano go na sekretarza KTD (Rocznik LVII Krakowskiego... 1876: 22). W ramach podjętych obowiązków przygotowywał m.in. sprawozdania Rady Ogólnej, które zamieszczane były w kolejnych tomach „Roczników Krakowskiego Towarzystwa Dobroczynności”. Włączył się ponadto w prace nad uporządkowaniem archiwum Towarzystwa, a na wniosek przewodniczącego Komisji Archiwalnej Jana Gwiazdomorskiego został powołany na członka tejże Komisji w 1882 roku dla ,jej wzmocnienia" (Posiedzenie zwyczajne w dniu 4 sierpnia 1872 roku odbyte: 237; Protokół z posiedzenia zwyczajnego Rady Ogólnej w dniu 5 lutego 1882: 673; Rocznik LXIII Krakowskiego... 1882: 34, 47). W połowie lat 80. XIX wieku wchodził w skład komisji opracowującej nowy statut KTD, który został zatwierdzony w roku 1885 (był także referentem poprzedniego statutu z 1874 roku) (Protokół z posiedzenia 4go nadzwyczajnego odbytego w dniu 13 lutego 1885...: 1035; Rocznik LXVII Krakowskiego... 1886: 9).

$\mathrm{Na}$ uwage zasługuje zaangażowanie Cyfrowicza w doskonalenie działalności KTD w zakresie kształcenia sierot oraz ich wychowania. Na posiedzeniu Rady Ogólnej 1 XI 1874 roku prezentował projekt powołania tzw. Komisji Szkolnej (Posiedzenie zwyczajne w dniu 1 listopada 1874 roku odbyte: 559). Był to organ KTD odpowiedzialny za kształcenie i wychowanie dzieci w zakładzie KTD. Składał się z przewodniczącego oraz dwóch członków. Podlegała mu istniejąca od 1820 roku tzw. szkoła codzienna, w której kształcono sieroty pozostające 
pod opieką KTD (Instrukcja 1874: 7). Decyzją Rady Ogólnej wszelkie sprawy dotyczące wychowania dzieci oraz pisma adresowane do Komisji Szkolnej były rozpatrywane przez Cyfrowicza (Posiedzenie zwyczajne w dniu 1 listopada 1874 roku odbyte: 559; Protokół z posiedzenia zwyczajnego Rady Ogólnej Krakowskiego Towarzystwa Dobroczynności dnia 7 lutego 1875 roku: 627). W 1881 roku pełnif funkcję przewodniczącego Komisji Szkolnej, po raz kolejny w roku 1886 został powołany na jej przewodniczącego w miejsce profesora UJ Maurycego Fiericha (Rocznik LXIII Krakowskiego... 1882: 34; Rocznik LXVIII Krakowskiego... 1887: 8). Działalność w tejże Komisji zakończyła jego śmierć w 1904 roku. Na zebraniach Rady Ogólnej rozpatrywane były zgłaszane przez niego zmiany w zapisach umów z urzędnikami płatnymi KTD mającymi pod opieką dzieci, np. katechetą. Powoływany był na zebrania odbywane w trybie nadzwyczajnym, na których rozwiązywano trudne dla Towarzystwa sprawy personalne (Posiedzenie zwyczajne w dniu 12 kwietnia 1874 roku odbyte: 483). Podczas posiedzeń Rady Ogólnej przekazywał wszelkie informacje, które dotyczyły działalności edukacyjnej i wychowawczej w zakładzie KTD. Powiadamiał m.in. o dobroczynnych gestach na rzecz szkoły Towarzystwa, zwłaszcza materiałach umożliwiających naukę praktyczną. Przykładem był ofiarowany przez Józefa Patelskiego zbiór 107 słoików z różnymi nasionami używanymi w gospodarstwie (Posiedzenie zwyczajne w dniu 12 kwietnia 1874 roku odbyte: 571). Sam również starał się doposażyć szkołę w materiały dydaktyczne, ofiarowując np. 20 egzemplarzy śpiewników zawierających świeckie piosenki, przeznaczał pieniądze na prezenty świąteczne dla dzieci. Pełniąc funkcję przewodniczącego Wydziału Spisu, przedstawiał na posiedzeniach prośby wychowanków o zapomogę, w tym prośby byłych podopiecznych o zapomogi na tzw. wyzwoliny w kwocie 25 złr. w.a. (Protokół z posiedzenia zwyczajnego Rady Ogólnej w dniu 18 czerwca 1882: 705; Protokół z posiedzenia zwyczajnego Rady Ogólnej w dniu 28 października 1883: 857). Stanowczo sprzeciwiał się sytuacjom, kiedy podnoszono w czasie zebrań Rady Ogólnej kwestie opieki nad dziećmi, wskazując zwłaszcza na jej nieprawidłowości. Oburzało go, że przekazywane były niesprawdzone informacje, które mogły wpłynąć niekorzystnie na ocenę działalności nauczyciela szkoły oraz Komisji Szkolnej. Uważał, że zakład KTD oraz posiedzenia Rady Ogólnej to nie sejm, gdzie wnosi się interpelacje i nagłaśnia 
kwestie, które można było wyjaśnić w czasie rozmowy z kompetentnymi osobami opiekującymi się dziećmi. Zdarzało się, że nie tylko tłumaczył, jakie wydarzenia miały miejsce w zakładzie, ale równocześnie uświadamiał i przypominał członkom zarządu z jakimi problemami borykały się przed przyjęciem do zakładu dzieci, z jakimi nawykami przychodziły, a także jakie zachowania należało zmienić. Uświadamiał w ten sposób, jak trudne zadanie realizował nauczyciel oraz opiekujące się dziećmi dwie kobiety, nazywane ochmistrzyniami (Protokół z posiedzenia zwyczajnego Rady Ogólnej w dniu 3 października 1886: 1235-1227). Nie zgadzał się, aby zdrowie dzieci było narażane przez te osoby, nawet dla zrealizowania przyjętego zwyczaju składania życzeń świątecznych dobroczyńcom. Jako przewodniczący Komisji Szkolnej zażądał 5 lutego 1888 roku wyjaśnień od nauczyciela szkoły codziennej dotyczących powodów dwukrotnych wypraw dzieci do domów dobroczyńców KTD podczas wielkich mrozów w święta Bożego Narodzenia w celu złożenia im życzeń świątecznych (Protokół z posiedzenia zwyczajnego Rady Ogólnej w dniu 5 lutego 1888: 1429). Zaznaczyć należy, że Cyfrowicz dokładał starań, aby rzetelna praca i wysiłek nauczyciela oraz uczniów były nagradzane przez Radę Ogólną. Jego zdaniem Komisja Szkolna powinna składać wnioski o przyznanie nagród uczniom szkoły KTD, nauczyciel zaś miał podawać nazwiska uczniów, którzy zasłużyli w danym roku szkolnym na wyróżnienie (Protokół z posiedzenia zwyczajnego Rady Ogólnej w dniu 7 kwietnia 1889: 1593).

Szczególne starania podjęła Komisja Szkolna, zwłaszcza jej przewodniczący Cyfrowicz, o realizację zadań związanych z wychowaniem pozostających pod opieką KTD dzieci „na pożytecznych członków społeczeństwa" (Rocznik LXVIII Krakowskiego... 1887: 3). W celu wdrożenia tych założeń 1 VII 1886 roku w Domu Sierot otwarto tzw. salę rzemiosł. Jako zwolennik praktycznego kształcenia dzieci w zakładzie Cyfrowicz dołożył wszelkich starań, aby powstała tam sala praktycznej nauki zawodu. Docenił te wysiłki prezes KTD dr Władysław Ściborowski (1833-1903), dziękując mu na zebraniu Rady Ogólnej w dniu 3 X 1886 roku za zaangażowanie w powołanie sali rzemiosł (Protokół z posiedzenia zwyczajnego Rady Ogólnej w dniu 3 października 1886: 1234). Upowszechniając ideę praktycznego przygotowania sierot oraz zachęcając mieszkańców Krakowa do wspierania działalności sali rzemiosł, Cyfrowicz zamieścił 
w „Roczniku Krakowskiego Towarzystwa Dobroczynności” relację z jej założenia i dotychczasowej działalności (Rocznik LXVIII Krakowskiego... 1887: 57). Po trzech latach, w 1889 roku, przedstawił działalność szkoły rzemiosł w „Roczniku Krakowskiego Towarzystwa Dobroczynności”. Poinformował, że została ona przekształcona z sali rzemiosł na szkołę rzemiosł. Zwrócił zarazem uwagę czytelników, że nie cieszyła się ona należytym zainteresowaniem i wsparciem ze strony mężczyzn i kobiet będących członkami KTD, a także krakowian. Problemem w funkcjonowaniu szkoły był również utrudniony nabór do niej sierot będących podopiecznymi Towarzystwa. Dzieci musiały, zgodnie z zapisem w statucie KTD, opuścić zakład po ukończeniu istniejącej tam szkoły codziennej, czyli chłopcy po 14 roku życia, a dziewczęta po ukończeniu 16 lat. Zdaniem Cyfrowicza, dopiero po zakończonej edukacji w szkole codziennej dzieci miały czas, odpowiedni wiek oraz siły fizyczne na naukę rzemiosła. Na taką naukę podczas trwania zajęć w szkole codziennej mogły przeznaczyć nie więcej niż dwie godziny dziennie, a był to zbyt krótki czas na doskonalenie umiejętności praktycznych i naukę zawodu. Ponadto miały wówczas za mało lat i sił fizycznych. Tymczasem statut nie pozwalał na dalsze ich utrzymywanie, na przeszkodzie stała również duża liczba sierot oczekujących na zwolnienie się miejsca w zakładzie KTD (Rocznik LXXI Krakowskiego... 1890: 47). Przedstawiając wstępne rezultaty działania szkoły rzemiosł, po upływie trzech lat, zaznaczył, że miała ona dobry wpływ nie tylko na umiejętności dziewcząt oraz chłopców, ale również w pewnym stopniu na budżet zakładu. Jej podopieczni, ucząc się, wykonywali zarazem drobne prace stolarskie, szewskie, krawieckie itp. Koszty funkcjonowania szkoły nie były wysokie, ponieważ materiału do nauki praktycznej dostarczał sam zakład w postaci koniecznych do wykonania prac naprawczych. Niezbędny był jedynie zakup drobniejszych materiałów. W opinii Cyfrowicza szkoła rzemiosł była bardzo potrzebna dzieciom, mogła je wspomóc w przygotowaniu do pracy zawodowej, a także umożliwić KTD realizację celu, jakim było przygotowanie dzieci do podjęcia pracy zarobkowej, która dawała szansę ma samodzielne utrzymywanie się (Rocznik LXXI Krakowskiego... 1890: 48-49).

Dzięki staraniom Cyfrowicza i Komisji Szkolnej wprowadzono naukę gimnastyki dla 40 dzieci, które przebywały w zakładzie KTD.W dniu 5 V 1889 roku Rada Ogólna, wydając zgodę na zajęcia 
z gimnastyki, zezwoliła zakup potrzebnych przyrządów gimnastycznych. Nauczyciel gimnastyki ze Stowarzyszenia „Sokół” pan Gędłek podjął się prowadzenia nieodpłatnie zajęć z dziećmi. Nadzór nad nauką gimnastyki powierzono radcy Magistratu, członkowi Komisji Szkolnej Ludwikowi Zawiłowskiemu (Rocznik LXXI Krakowskiego... 1890: 51-52).

W trosce o warunki życia w zakładzie oraz stan higieny Cyfrowicz poruszał na zebraniach Rady Ogólnej szczegółowe kwestie dotyczące codziennego życia podopiecznych. Zwracał uwagę, że zwierzęta, które przebywają w zakładzie, zwłaszcza bezpańskie psy, wpływały negatywnie na stan sanitarny pomieszczeń (Protokól z posiedzenia zwyczajnego Rady Ogólnej w dniu 19 kwietnia 1883: 1071). Dostrzegał i sygnalizował potrzebę otoczenia opieką osób, które nie miały gdzie przetrwać zimowych, mroźnych dni i prosiły o przyjęcie na ten okres do zakładu. Rada Ogólna nie zezwoliła, uzasadniając odmowę zapisem w statucie, na organizowanie doraźnej pomocy i przyjmowanie czasowo potrzebujących na koszt KTD bądź wynajmowanie pomieszczeń (Protokół z posiedzenia zwyczajnego Rady Ogólnej w dniu 3 października 1886: 1237; Protokół z posiedzenia zwyczajnego Rady Ogólnej w dniu 12 lipca 1885: 1093). Troszcząc się o dobre warunki w zakładzie, był przekonany, że należało złożyć wniosek o założenie oświetlenia gazowego w czasie, gdy prace te wykonywano na ul. Koletek, w dzielnicy Stradom, gdzie znajdował się budynek zakładu KTD (Protokół z posiedzenia zwyczajnego Rady Ogólnej w dniu 7 kwietnia 1889: 1593).

W latach 90. XIX wieku, jako osoba wyznaczona przez Radę Ogólną, Cyfrowicz podjął działania zmierzające do zrealizowania planu odnowienia obrazu i ołtarza Matki Boskiej w Bramie Floriańskiej. Ołtarzem oraz obrazem w Bramie Floriańskiej opiekowało się KTD na postawie upoważnienia Senatu Rządzącego Wolnego Miasta Krakowa z dnia 8 III 1817 roku. W dniu 17 III 1817 roku potwierdzono prawo Towarzystwa do opieki oraz pobierania datków dla ubogich. Przy ołtarzu umieszczona została skarbona, do której ludzie przechodzący przez Bramę Floriańską mogli wrzucać pieniądze w celu wspomożenia ubogich umieszczonych w zakładzie KTD (Pismo Wydziału... 1817: nlb). Na posiedzeniu Rady Ogólnej w dniu 19 IV 1895 roku Cyfrowicz wyznaczony został przez do podjęcia kroków zmierzających do restauracji ołtarza w Bramie Floriańskiej 
oraz znajdującego się tam obrazu Maki Boskiej. W tym celu kontaktował się z konserwatorem zabytków Stanisławem Tomkowiczem (1850-1933), znawcą dziejów sztuki oraz konserwacji zabytków, jak również z hrabiną Stanisławową Tarnowską (Pagaczewski 1935: $\left.1^{*}-4^{*}\right)$. Cyfrowicz zwracał uwagę, że nie tylko odnowienie, ale i przeniesienie obrazu wydawało się konieczne $z$ uwagi na niebezpieczeństwo, na jakie narażeni mogli być modlący się ludzie ze strony przejeżdżającego tramwaju (Pismo L. Cyfrowicza... 1896: nlb). Komisja podjęła działanie i w 1904 roku mieszkańcy Krakowa oraz przyjezdni mogli oglądać efekt prac w postaci odnowionego ołtarza oraz obrazu (Pismo Rady Ogólnej... 1907: nlb).

Do działalności na polu dobroczynności Cyfrowicza odniósł się w 1882 roku Hoszowski, wieloletni prezes KTD. Była to odpowiedź na artykuł w „Gazecie Krakowskiej” (1981), zamieszczony w dziale zatytułowanym „Sprawy Miejskie”, a poświęcony działalności KTD. Prezes przypominał, że w połowie lat 70.XIX wieku przeprowadzono zmiany w funkcjonowaniu istniejącej w zakładzie szkoły codziennej, których inicjatorem i wykonawcą był Cyfrowicz. Hoszowski podkreślił zarazem, że działanie to był „odnowieniem” szkoły, dostosowaniem pracy nauczyciela, katechety oraz osób opiekujących się dziećmi do ówczesnych wymogów władz szkolnych, jak również potrzeb dzieci. Stanowczo sprzeciwił się natomiast nazywaniem tych działań mianem reformy Towarzystwa przeprowadzonej przez m.in. Cyfrowicza, a w taki sposób określiła jego zaangażowanie „Gazeta Krakowska” (Sprawy Miejskie 1881: 2; Hoszowski 1882: 10,12). Przypominając udział poszczególnych osób w przygotowaniu dokumentów normujących działalność szkoły, Hoszowski nadmienił, że Cyfrowicz brał udział w opracowaniu instrukcji dla Komisji Archiwalnej (wraz z Janem Gwiazdomorskim i Franciszkiem Bartynowskim), Instrukcji dla Komisji Szkolnej i nauczyciela szkoły sierot (razem z Henrykiem Maciołowskim, ks. Chmielewskim). Hoszowski zaznaczył również, że Cyfrowicz wchodził w skład komitetu budowy nowego domu dla podopiecznych KTD, podobnie jak Jan Gwiazdomorski oraz Jan Hajdukiewicz (Hoszowski 1882: 14). Jego zdaniem wspólna praca oraz wysiłek wielu osób doprowadziły do zakończenia budowy nowego gmachu i umożliwiły umieszczenie sierot i starców pod jednym dachem (Wnioski Komisji... 1880: 511-513). W „Roczniku Krakowskiego Towarzystwa Dobroczynności” Cyfrowicz w uznaniu 
zasług dla Towarzystwa wymieniony został jako członek honorowy KTD, razem z Katarzyną z hrabiów Branickich Potocką, dr Leonem Hajdukiewiczem, Henrykiem Schwartzem (Rocznik LXXXV Krakowskiego... 1904: 9).

\section{Zakończenie}

Podsumowując, należy podkreślić, że Leon Cyfrowicz należał do elitarnego grona inteligencji krakowskiej, którą stanowili wykładowcy Uniwersytetu Jagiellońskiego. Podejmował się bardzo wielu różnorodnych zadań. Pracował w redakcji „Czasu”, prowadził wykłady na UJ, był sekretarzem i kierownikiem kancelarii UJ. Należał do najstarszych instytucji dobroczynnych w Krakowie, tj. Arcybractwa Miłosierdzia i Banku Pobożnego oraz Krakowskiego Towarzystwa Dobroczynności. Podjęta przez niego współpraca z KTD ukierunkowana była na pomoc dzieciom, sierotom pozostającym pod opieką Towarzystwa. Dążył do nadania praktycznego kierunku ich kształceniu, umożliwienia im zdobycia takich umiejętności, które ułatwiłyby im w przyszłości znalezienie pracy. Taki kierunek przygotowania dzieci do życia po opuszczeniu zakładu przyjęły powołane w pierwszej połowie XIX wieku najstarsze Towarzystwa Dobroczynności na ziemiach polskich, w Wilnie, Warszawie. Służył ubogim ludziom pomocą, wykorzystując swoją wiedzę i umiejętności organizacyjne, zawodowe, obserwował rzeczywistość i na łamach wydawanych publikacji pisał o potrzebie zmian. Nie wahał się mówić podczas zebrań KTD o błędnych decyzjach i stawać w obronie podopiecznych.

\section{Bibliografıa}

\section{Materiały źródłowe}

Archiwum Narodowe w Krakowie, Akta obrazu Matki Boskiej w Bramie Floriańskiej będącego pod opieką Towarzystwa Dobroczynności 1817-1945, sygn. 547/427, 86 k., rkps.

- Pismo L. Cyfrowicza do Rady Ogólnej z 4 XII 1896 r., nlb. (w dokumentach nie znaleziono pisma konserwatora określającego wartość obrazu i ołtarza).

- Pismo Rady Ogólnej do Władysława Pochwalskiego z dn. 9 X 1907 r., nlb. 
- Pismo Wydziału Spraw Wewnętrznych i Sprawiedliwości w Senacie Rządzącym Wolnego, Niepodległego i ściśle Neutralnego Miasta Krakowa i jego okręgu do prezesa KTD z 17 III 1817 r., nlb.

Archiwum Narodowe w Krakowie, Siódmy Tom Protokołu Rady Ogólnej

Towarzystwa Dobroczynności w Krakowie od dnia 18 maja 1870 roku rozpoczęty [do roku 1875], sygn. 547/7, 760 k., rkps.

- Protokół z posiedzenia zwyczajnego Rady Ogólnej w dniu 16 czerwca 1872.

- Posiedzenie zwyczajne w dniu 4 sierpnia 1872 roku odbyte.

- Posiedzenie zwyczajne w dniu 12 kwietnia 1874 roku odbyte.

- Posiedzenie zwyczajne w dniu 1 listopada 1874 roku odbyte.

- Posiedzenie zwyczajne w dniu 15 listopada 1874 roku odbyte.

- Protokól z posiedzenia zwyczajnego Rady Ogólnej Krakowskiego Towarzystwa Dobroczynności dnia 7 lutego 1875 roku.

Archiwum Narodowe w Krakowie, Ósmy Tom Protokołu Rady Ogólnej Towarzystwa Dobroczynności w Krakowie rozpoczęty dnia 4 lipca 1875 do 4 września 1892, sygn. 547/8, 2180 k., rkps.

- Protokół z posiedzenia zwyczajnego Rady Ogólnej w dn. 5 lutego 1882.

- Protokół z posiedzenia 4go nadzwyczajnego odbytego w dniu 13 lutego 1885 r. o godzinie 3 po południu w Sali Arcybractwa Miłosierdzia i Banku Pobożnego przy ulicy Siennej.

- Protokół z posiedzenia zwyczajnego Rady Ogólnej w dniu 5 lutego 1882.

- Protokół z posiedzenia zwyczajnego Rady Ogólnej w dniu 18 czerwca 1882.

- Protokół z posiedzenia zwyczajnego Rady Ogólnej w dniu 19 kwietnia 1883.

- Protokół z posiedzenia zwyczajnego Rady Ogólnej w dniu 28 października 1883.

- Protokół z posiedzenia zwyczajnego Rady Ogólnej w dniu 12 lipca 1885.

- Protokół z posiedzenia zwyczajnego Rady Ogólnej w dniu 3 października 1886.

- Protokół z posiedzenia zwyczajnego Rady Ogólnej w dniu 5 lutego 1888.

- Protokół z posiedzenia zwyczajnego Rady Ogólnej w dniu 7 kwietnia 1889.

- Wnioski Komisji budowy domu Towarzystwa dobroczynności do zatwierdzenia i uchwalenia na posiedzeniu w dniu 28 maja $1880 \mathrm{r}$. Radzie Towarzystwa Dobroczynności przedłożone.

Almanach jubileuszowy Uniwersytetu Jagiellońskiego z kalendarzem na lata 1900 i 1901 (1900). Kraków: Drukarnia Akademicka pod zarządem Józefa Filipowskiego. 
Cyfrowicz L. (1869). Zdania z różnych gatęzi prawa i umiejętności politycznych, których po odbyciu egzaminów ścistych w celu uzyskania godności doktora obojga praw na c.k. Uniwersytecie Jagiellonskim w Krakowie Leon Cyfrowicz Krakowianin we środe 10 Marca 1869 o godz. 12 w potudnie w Kolegium Prawniczem publicznie bronić się podejmuje, Kraków: Druk c.k. Wszechnicy Jagiellońskiej.

Cyfrowicz L. (1878). Kilka stów o dziatalności instytucji dobroczynnych w Krakowie, Kraków: Drukarnia „Czasu”.

Cyfrowicz L. (1879). Przemówienie przy ztożeniu do grobu zwtok s.p. Ludwika Georgeona wtaściciela pensjonatu wychowawczo-naukowego $i$ radcy Towarzystwa Dobroczynności zmartego w Kaltenleutgeben pod Wiedniem d. 3 sierpnia 1879 r. miane dnia 6 sierpnia 1879 roku na cmentarzu krakowskim, Kraków: Czcionkami Drukarni „Czasu”.

Cyfrowicz L. (1884a). Nowe przepisy egzaminacyjne dla kandydatów na nauczycieli w gimnazjach i szkołach realnych, Kraków: Drukarnia Uniwersytetu Jagiellońskiego.

Cyfrowicz L. (1884b). Obraz Matki Boskiej i skarbonka ubogich w Bramie Floriańskiej w Krakowie, Kraków: W Drukarni „Czasu” Fr. Kluczyckiego i spółki.

Cyfrowicz L. (1885). O ubóstwie ze stanowiska administracyjnego, Kraków: W Drukarni „Czasu” Fr. Kluczyckiego i spółki.

Cyfrowicz L. (1889). Wyktad austriackiego prawa administracyjnego, Kraków: W Drukarni „Czasu” Fr. Kluczyckiego i spółki.

Cyfrowicz Leon (1 IV 1844 Kraków - 23 V 1904 tamże) (2000). [w:] Encyklopedia Krakowa, Warszawa-Kraków: Wydawnictwo Naukowe PWN, s. 132.

Instrukcja dla nauczyciela szkoty sierót w Krakowskim Towarzystwie Dobroczynności istniejącej (1875). Kraków: Czcionkami Drukarni „Czasu”, s. 1-7.

Pamiętnik Towarzystwa Dobroczynności Krakowskiego wydany z powodu obchodzonego w d. 24 i 25 czerwca 1866 r. pięćdziesiąt-letniego jubileuszu wskrzeszenia w roku 1816 tegoż Towarzystwa (1868). Kraków: W Drukarni „Czasu”W. Kirchmayera.

Rocznik LVII Krakowskiego Towarzystwa Dobroczynności z roku 1875 (1876). Kraków: Czcionkami Drukarni „Czasu”.

Rocznik LXIII Krakowskiego Towarzystwa Dobroczynności z roku 1881 (1882). Kraków: Czcionkami Drukarni „Czasu”.

Rocznik LXVII Krakowskiego Towarzystwa Dobroczynności z roku 1885 (1886). Kraków: W drukarni Czasu Franciszka Kluczyckiego i spółki.

Rocznik LXVIII Krakowskiego Towarzystwa Dobroczynności z roku 1886 (1887). Kraków: W drukarni Czasu Franciszka Kluczyckiego i spółki.

Rocznik LXXI Krakowskiego Towarzystwa Dobroczynności z roku 1889 (1890). Kraków: W drukarni Czasu Franciszka Kluczyckiego i spółki. 
Rocznik LXXXV Krakowskiego Towarzystwa Dobroczynności z roku 1903

(1904). Kraków: W drukarni Czasu Franciszka Kluczyckiego i spółki.

Sprawy Miejskie (1881). „Gazeta Krakowska” 22 maja, nr 14, s. 2.

$W$ trzydziesta rocznice powstania styczniowego. Kilka stów o polityce narodowej

(1893). Kraków: Czcionkami Drukarni Związkowej.

Wybory (1881). „Krakowianin. Pismo dwutygodniowe”, 9 lipca, nr 10, s. 1-2.

\section{Opracowania}

Bieniarzówna J. (1985). Od Wiosny Ludów do powstania styczniowego, [w:] J. Bieniarzówna, J.M. Małecki (red), Dzieje Krakowa. Kraków w latach 1796-1918, t. 3, Kraków: Wydawnictwo Literackie Kraków, s. 177-211.

Chodakowska J. (1990). Ksztatcenie nauczycieli szkót średnich w uniwersytetach galicyjskich na przetomie XIX i XX wieku, „Rozprawy z Dziejów Oświaty", t. 33, s. 153-184.

Dybiec J. (2011). Nauka w Galicji. Stan i potrzeby badań, [w:] A. Kawalec, W. Wierzbieniec, L. Zaszkliniak (red.), Galicja 1772-1918, t. 2, Rzeszów: Wydawnictwo Uniwersytetu Rzeszowskiego, s. 267-285.

Flach J. (1917). Politycy galicyjscy, Piotrogród: Księgarnia Polska.

Grodziski S. (1995). Miejsce i rola Uniwersytetu Jagiellońskiego w Sejmie Krajowym Galicyjskim, [w:] J. Malec, W. Uruszczak (red.), Dawne prawo i myśl prawnicza. Prace historyczno-prawne poświęcone pamięci Wojciecha Marii Bartla, Kraków: Księgarnia Akademicka, s. 207-226.

Hoszowski K. (1882). Przyczynek do historii Krakowskiego Towarzystwa Dobroczynności, Kraków: W Drukarni Uniwersytetu Jagiellońskiego.

Karolczak K. (1995). Struktura spoteczna Krakowa na przetomie XIX i XX wieku, [w:] J. Chłopecki, H. Madurowicz-Urbańska (red.), Galicja i jej dziedzictwo, t. 2: Spoteczeństwo i gospodarka, Rzeszów: Wydawnictwo Wyższej Szkoły Pedagogicznej, s. 209-223.

Ksią̇ka pamiątkowa Arcybractwa Mitosierdzia i Banku Pobożnego w Krakowie od roku 1584 do 1884 skreślona w roku jubileuszowym (1884). Kraków: W drukarni Czasu Franciszka Kluczyckiego i spółki.

Księga pamiatkowa na dziewiéćdziesiolecie dziennika „Czas” (1938). Warszawa: Drukarnia Polska.

Meissner A. (2011). Oświata w Galicji. Stan i potrzeby badań, [w:] A. Kawalec, W. Wierzbieniec, L. Zaszkliniak (red.), Galicja 1772-1918, t. 3, Rzeszów: Wydawnictwo Uniwersytetu Rzeszowskiego, s. 9-24.

Miśko D. (1891). Historia zatożenia i rozwoju Towarzystwa Wzajemnej Pomocy Uczniów Uniwersytetu Jagiellonskiego w 25 rocznice jubileuszowa, Kraków: Nakładem Towarzystwa Wzajemnej Pomocy Uczniów Uniwersytetu Jagiellońskiego.

„Nowa Reforma” (1904). 23 maja, nr 118, s. 3. 
Pagaczewski J. (1935). Stanistaw Tomkowicz (wspomnienie pośmiertne), „Prace Komisji Historii Sztuki”, t. 6, z. 1, Kraków: Nakładem Polskiej Akademii Umiejętności, s. $1^{*}-4$.

Sempołowska S. (1906). Niedola mtodzieży w szkole galicyjskiej (Kilka stów o narodowej szkole w Galicji), Kraków: Drukarnia Władysława Teodorczuka.

Stinia M. (2014). Uniwersytet Jagielloński w latach 1871-1914. Modernizacja procesu nauczania, Kraków: Wydawnictwo Uniwersytetu Jagiellońskiego.

Tomkowicz Stanistaw (28 V 1850 Kraków - 11 III 1933 tami̇e). (2000). [w:] Encyklopedia Krakowa. Warszawa-Kraków: Wydawnictwo Naukowe PWN, s. 998.

Zgórniak M. (1964). Mtodzież akademicka Uniwersytetu Jagiellońskiego wobec wydarzeń politycznych lat 1846-1866, [w:] C. Bobińska (red.), Studia z dziejów mtodzieży Uniwersytetu Krakowskiego od Oświecenia do potowy XX wieku, t. 1, Kraków: Uniwersytet Jagielloński, s. 107-167.

Żukowski P.M. (2016). Od profesora do urzednika. Sekretarze Uniwersytetu Jagiellonskiego w Krakowie w drugiej potowie XIX $i$ w poczatkach XX wieku, [w:] T. Bykowa, A. Górak, G. Smyk (red.), Dzieje biurokracji, t. 6, Lublin: Wydawnictwo: ToNiK „Libra”, s. 349-363.

\section{ADRES DO KORESPONDENCJI}

\section{Dr Ewa Barnaś-Baran}

Uniwersytet Rzeszowski

Instytut Pedagogiki

Zakład Historii i Teorii Wychowania

e-mail: ewa.bb@ur.edu.pl 